Syntax Literate: Jurnal Ilmiah Indonesia p-ISSN: 2541-0849 e-ISSN: 2548-1398

Vol. 6, No. 1, Januari 2021

\title{
KAJIAN SUMBER DAYA MANUSIA PROSES JASA SARANA FISIK DAN DAMPAKNYA PADA KEPUASAN MASYARAKAT
}

\section{Aditya Christian Paulus dan Muhammad Iqbal Baihaqi}

Universitas Katolik Parahyangan Bandung Jawa Barat, Indonesia

Email: aditylee19995@gmail.com dan iqbalbaihaqi62@gmai.com

\begin{abstract}
Marketing management plays an important role in increasing customer satisfaction, one of which is the marketing mix of services consisting of human resources, processes and physical facilities. This variable is very important in increasing satisfaction. This study aims to determine how much influence the human resources services and physical facilities on community satisfaction of batujajar barat village in the government sector, both partially and simultaneously where the research methods used are descriptive and verification methods. The population of this study is the west batujajar village community, which amounts to around 15,000 people with a sample of 100 respondents where the analysis of the data technique used is multiple linear regression techniques of correlation and the coefficient of determination. The results showed that the human resources of the village apparatus could be said to be not good in terms of competence, attitude and knowledge, and the service process, it could be said to be not good in terms of speed, ease of procedure and time certainty. Furthermore, west batujajar village human resource services and physical facilities significantly affect community satisfaction in the west batujajar village both partially and simultaneously with a sign value $<5 \%$.
\end{abstract}

Keywords: service marketing; customer satisfaction; human resources; physical facility

\begin{abstract}
Manajemen pemasaran memainkan peran penting dalam meningkatkan kepuasan pelanggan, salah satunya adalah bauran pemasaran layanan yang terdiri dari sumber daya manusia, proses dan fasilitas fisik. Variabel ini sangat penting dalam meningkatkan kepuasan. Penelitian ini bertujuan untuk mengetahui seberapa besar pengaruh layanan sumber daya manusia dan fasilitas fisik terhadap kepuasan masyarakat Desa Batujajar Barat di sektor pemerintahan, baik secara parsial maupun simultan dimana metode penelitian yang digunakan adalah metode deskriptif dan verifikatif. Populasi penelitian ini adalah komunitas Desa Batujajar Barat, yang berjumlah sekitar 15.000 orang dengan sampel 100 responden dimana analisis teknik data yang digunakan adalah teknik regresi linier berganda korelasi dan koefisien determinasi. Hasil penelitian menunjukkan bahwa sumber daya manusia perangkat desa dapat dikatakan tidak baik dalam hal kompetensi, sikap dan pengetahuan, serta proses pelayanan, dapat dikatakan tidak baik dalam hal kecepatan, kemudahan prosedur dan waktu kepastian. Selanjutnya, layanan sumber daya manusia dan fasilitas fisik Desa Batujajar Barat secara signifikan
\end{abstract}


mempengaruhi kepuasan masyarakat di Desa Batujajar Barat baik secara parsial maupun simultan dengan nilai tanda $<5 \%$.

Kata kunci: pemasaran jasa; kepuasan pelanggan; sumber daya manusia; fasilitas fisik

Coresponden Author

Email: aditylee19995@gmail.com

Artikel dengan akses terbuka dibawah lisensi

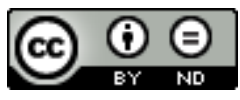

\section{Pendahuluan}

Pembangunan desa mempunyai peranan penting dan strategis dalam rangka pembangunan nasional dan pembangunan daerah, karena didalamnya terkandung unsur pemerataan pembangunan dan hasil-hasilnya menyentuh secara langsung kepentingan sebagian besar masyarakat yang bermukim di pedesaan dalam rangka upaya meningkatkan kesejahteraan desa.

Pemerintahan desa merupakan sektor terdepan dalam negara sebagai pelaksana pembangunan. Pentingnya peran desa pada masa pemerintahan saat ini dituntut harus mengedepankan pelayanan yang baik kepada masyarakat guna meningkatkan taraf hidup masyarakat.

Pemerintahan desa dituntut untuk terus meningkatkan pelayanannya kepada masyarakat karena sebagai garda terdepan dalam pembangunan negara. Sesuai pasal 24 Undang-Undang nomor 6 (enam) tahun 2014 guna meningkatkan pelayanan kepada masyarakat secara optimal maka pemerintahan desa harus menyelenggarakan pelayanan berdasarkan asas: (1) kepastian hukum; (2) tertib penyelenggaraan pemerintahan; (3) tertib kepentingan umum; (4) keterbukaan (5) proporsionalitas; (6) profesionalitas; (7) akuntabilitas; (8) efektivitas; dan (9) efisiensi. Pelaksanaan asas-asas tersebut akan mampu meningkatkan kepuasan masyarakat.

Faktor-faktor yang mempengaruhi tingkat kepuasan konsumen adalah kualitas produk atau jasa. Setelah membeli dan menggunakan produk tersebut ternyata kualitas produk atau jasanya baik dan didukung (Sufiyyah, 2011). Dapat ditekankan bahwa kualitas jasa pemerintahan desa yang baik akan mempengaruhi kepuasan masyarakat. Kemudian didukung dengan penelitian lainnya dari (Khoirul, 2012) yang menjelaskan bahwa terdapat Pengaruh kualitas pelayanan terhadap kepuasan nasabah. Kepuasan konsumen juga dapat diraih jika konsumen turut mendapatkan keuntungan (Mulyawan \& Rinawati, 2017). Selain itu, kepuasan konsumen juga mempengaruhi loyalitas konsumen (Nasution, 2011) yang didukung oleh (Qomariah, 2012). Menurut (Ilyas et al., 2010), kepuasan konsumen sangat penting untuk menghadapi persaingan dengan kompetitor. Dilihat dari segi konsumen, dimana gaya hidup konsumen mengalami perubahan, maka suatu organisasi jasa perlu beradaptasi dengan perubahan tersebut agar tercipta kepuasan konsumen yang konstan (Sudiarta, 2011) dan didukung oleh (Suprapti, 2010). 
Desa berkewajiban untuk terus meningkatkan kualitas jasa dan meningkat sarana prasarana kepada masyarakat dan mengembangkan kehidupan demokrasi mengembangkan pemberdayaan masyarakat desa. Sebagaimana di sebutkan dalam undang undang republik indonesia No 6. Tahun 2014 dikatakan bahwa desa adalah desa dan desa adat atau yang disebut dengan nama lain, selanjutnya disebut desa, adalah kesatuan masyarakat hukum yang memiliki batas wilayah yang berwenang untuk mengatur dan mengurus urusan pemerintahan, kepentingan masyarakat setempat berdasarkan prakarsa masyarakat, hak asal usul, dan/atau hak tradisional yang diakui dan dihormati dalam sistem pemerintahan negara kesatuan republik indonesia.

Berdasarkan undang-undang republik indonesia No 25 tahun 2009 tentang pelayanan publik dijelaskan bahwa pelayanan publik adalah kegiatan atau rangkaian kegiatan dalam rangka pemenuhan kebutuhan pelayanan sesuai dengan peraturan perundang undangan bagi setiap warga negara dan penduduk atas barang, jasa, dan/atau pelayanan administratif yang disediakan oleh penyelenggara pelayanan publik.

Standar pelayanan adalah tolak ukur yang dipergunakan sebagai pedoman penyelenggaraan pelayanan dan acuan penilaian kualitas pelayanan sebagai kewajiban dan janji penyelenggara kepada masyarakat dalam rangka pelayanan yang berkualitas, cepat, mudah, terjangkau, dan terukur. Dengan melihat pentingnya peran pembangunan dan pelayanan pemerintahan desa batujajar barat terhadap kepuasan masyarakat dan berdasarkan uraian di atas maka penulis mengangkat judul "pemasaran jasa pada sektor pemerintahan (studi kasus pemerintahan desa batujajar barat).

Tujuan dari penelitian ini diantaranya untuk mengetahui dan menganalisa tanggapan masyarakat tentang: 1. Kualitas Sumber daya manusia Aparatur Desa Batujajar Barat 2. Proses jasa di Desa batujajar barat 3. Kualitas Sarana fisik Desa batujajar barat 4. Tingkat kepuasan Masyarakat Desa Batujajar Barat 5. besarnya pengaruh sumber daya manusia. Proses jasa dan sarana fisik pemerintahan desa batujajar barat terhadap kepuasan masyarakat desa Batujajar Barat baik secara farsial maupun simultan. Kegunaan dalam penelitian ini secara teoritis memberikan kontribusi terhadap perkembangan ilmu Manajemen khususnya Manajemen Pemasaran dan dapat dijadikan acuan bagi penelitian-penelitian lainnya. Kegunaan praktis penelitian ini diharapkan untuk mengetahui bagaimana kualitas sumber daya manusia Aparatur desa proses pelayanan dan kualitas sarana fisik desa Batujajar Barat. Penelitian ini diharapkan dapat mengetahui seberapa besar pengaruh Sumber daya manusia Proses Pelayanan dan sarana fisik pemerintahan desa batujajar barat terhadap kepuasan masyarakat desa batujajar barat baik secara farsial maupun simultan. Hasil penelitian ini diharapkan dapat menjadi masukan kepada Pemerintahan desa batujajar barat khususnya bagi pimpinan kepala desa batujajar barat untuk menjadi bahan acuan akan perbaikan perbaikan kedepannya.

Organisasi atau perusahaan pasti akan selalu berupaya untuk dapat mengatur segala kegiatan pemasaran perusahaan tersebut agar dapat sesuai dengan tujuan yang telah dibuat agar dapat mengelola dan juga mengatur seluruh kegiatan pemasaran tersebut dengan baik dan benar maka peran dari manajemen pemasaran sangat 
dibutuhkan sehingga dapat menunjang kegiatan pemasaran di perusahaan tersebut. Manajemen pemasaran yaitu terdiri dari berbagai aktivitas seperti merencanakan, menganalisa dan mengedalikan semua kegiatan pemasaran guna mencapai tujuan memilih pasar sasaran untuk mendapatkan, menjaga, dan menumbuhkan jumlah pelanggan agar dapat mencapai tujuan perusahaan. Menurut Philip (Kotler \& Keller, 2012), manajemen pemasaran adalah "seni dan ilmu memilih pasar sasaran dan meraih, mempertahankan, serta menumbuhkan pelanggan dengan menciptakan, menghantarkan, dan mengkomunikasikan nilai pelanggan yang unggul." Selanjutnya Menurut (Amstrong, 2012) pengertian manajemen pemasaran adalah sebagai berikut: Manajemen Pemasaran adalah penganalisaan, pelaksanaan, dan pengawasan, programprogram yang ditujukan utuk mengadakan pertukaran dengan pasar yang dituju dengan maksud untuk mencapai tujuan organisasi. Selanjutnya Pengertian pemasaran menurut (Fandy, 2011) Dalam bukunya Service Quality Satisfaction adalah sebagai berikut: "Pemasaran merupakan sistem sosial efektifitas bisnis yang dirancang untuk merencanakan, menetapkan harga, mempromosikan dan mendistribusikan produk, jasa, dan gagasan yang mampu memuaskan keinginan pasar dalam rangka mencapai tujuan organisasi. Dari berbagai pendapat di atas dapat disimpulkan bahwa Manajemen pemasaran adalah Suatu Seni atau ilmu pengetahuan tentang bagaimana caranya perusahaan atau organisasi menentukan target pasar memilih targer pasar dan menyiapkan strategi untuk merebut pasar tersebut dan meraih hati konsumen sesuai dengan apa yang dicita-citakan perusahaan yang pada dasarnya meraih laba menghantarkan nilai dan mencapai kepuasan konsumen maupun pelanggan. Salah satu sub ilmu dari manajemen pemasaran adalah pemasaran jasa. Jasa adalah bentuk produk yang terdiri dari aktivitas, manfaat, atau kepuasan yang ditawarkan untuk dijual dan pada dasarnya tak berwujud serta tidak menghasilkan kepemilikan akan sesuatu.

Menurut (Lupiyoadi \& Hamdani, 2011), jasa dapat diklasifikasikan berdasarkan tingkat kontak pelanggan dengan pemberi jasa sebagai bagian dari sistem saat jasa tersebut dihasilkan. Berdasarkan tingkat kontak pelanggan jasa dapat dibedakan ke dalam kelompok sistem kontak tinggi (high-contact system). Pada kelompok sistem kontak tinggi, pelanggan harus menjadi bagian dari sistem untuk menerima jasa, contohnya jasa pendidikan, rumah sakit dan transportasi. Sistem kontak rendah (lowcontact system). kelompok sistem kontak rendah, pelanggan tidak perlu menjadi bagian dari sistem untuk menerima jasa, contohnya jasa reparasi mobil dan jasa perbankan. Pelanggan tidak harus dalam kontak pada saat mobilnya yang rusak diperbaiki oleh teknisi bengkel. Dari pendapat diatas dapat disimpulkan bahwa jasa adalah Nilai manfaat yang ditawarkan oleh perusahaan atau organisasi kepada pelanggan yang sifatnya tidak berwujud tidak dapat dilihat dan diraba hanya dapat dirasakan oleh konsumen yang telah berhasil mencapai tingkat perasaan tertentu.

Indikator pelayanan publik menurut Kepmen PAN Republik Indonesia mengenai pelayanan publik diantaranya sebagai berikut : Keterbukaan, Indikator keterbukaan ini hanya terdapat dalam Kepmen PAN RI No. 58/2002. Indikator ini selanjutnya dibagi dalam 3 sub indikator, yaitu keterbukaan prosedur pelayanan, keterbukaan persyaratan 
pelayanan, dan keterbukaan biaya pelayanan. Kemudahan, Indikator kemudahan ini terdapat dalam dua Kepmen PAN, yaitu Kepmen PAN No. 63/2003 dan Kepmen PAN RI No. 25/2004, yang berkaitan dengan kemudahan alur pelayanan. Selain itu juga terdapat dalam servqual for citizen (NPS). Hasil gabungan tersebut melahirkan 3 sub indikator, yaitu kemudahan alur pelayanan, kemudahan memperoleh pelayanan dan kemudahan mengakses tempat pelayanan. Kepastian, Indikator kepastian ini terdapat dalam ketiga Kepmen PAN RI dan juga servqual serta servqual for citizen. Hasil gabungan dari ketiga Kepmen PAN dan servqual tersebut melahirkan 4 sub indikator, yaitu kepastian biaya pelayanan, kepastian waktu pelayanan, ketepatan waktu penyelesaian sesuai standar dan kepastian (kejelasan) satuan/petugas yang memberikan pelayanan. Keadilan, Indikator keadilan ini terdapat dalam Kepmen PAN No. 25/2004. Selain itu juga terdapat dalam servqual for citizen (NPS). Variabel ini hanya berkaitan dengan satu hal yaitu adil atau perlakuan yang sama ketika menerima pelayanan. Profesionalisme Petugas, Indikator ini terdapat dalam tiga Kepmen PAN, yaitu Kepmen PAN No. 58/2002, Kepmen PAN No. 63/2003 dan Kepmen PAN No. 25/2004. Selain itu juga terdapat dalam servqual Zeithml, dkk dan servqual for citizen (NPS). Hasil gabungan dari servqual dan Kepmen PAN untuk dimensi ini melahirkan 6 sub indikator, yaitu kedisiplinan petugas, tanggung jawab petugas, kemampuan petugas, kecepatan pelayanan, kesopanan dan keramahan petugas serta kejujuran petugas (tidak pungli). Sarana dan Fasilitas , Indikator ini terdapat tiga Kepmen PAN, yaitu Kepmen PAN No. 58/2002, Kepmen PAN No. 63/2003 dan Kepmen PAN No.25/2004.

Hasil gabungan dari servqual dan Kepmen PAN melahirkan 3 sub indikator, yaitu: ketersediaan sarana dan fasilitas, kenyamanan yang dirasakan dan ketersediaan fasilitas penunjang. Sektor jasa harus terus memperhatikan pelayanan prima untuk meningkatkan kepuasan konsumen atau masyarakat Pelayanan prima yang dikemukakan oleh (Barata, 2004) adalah "kepedulian kepada pelanggan dengan memberikan layanan terbaik untuk memfasilitasi kemudahan pemenuhan kebutuhan dan mewujudkan kepuasannya, agar mereka selalu loyal kepada organisasi/perusahaan". Menurut (Barata, 2004) pelayanan prima terdiri dari 6 unsur pokok, antara lain: Kemampuan, Sikap, Penampilan, Perhatian, Tindakan, Tanggung jawab, sebagaimana telah di jelaskan dari penelitian terdahulu (Dwi, 2009) bahwa pengaruh pelayanan prima non akademik dan pelayanan prima berpengaruh terhadap efektifitas organisasi.

\section{Metode Penelitian}

Penelitian yang dilakukan di pemerintahan desa batujajar barat terhadap kepuasan masyarakat di desa batujajar barat ini menggunakan metode penelitian kuantitatif. Menurut (Sugiyono, 2013), metode kuantitatif dapat diartikan sebagai metode penelitian yang berlandaskan pada filsafat positivisme digunakan untuk meneliti populasi atau sampel tertentu pengumpulan data menggunakan instrumen penelitian analisis data bersifat kuantitatif/statistik dengan tujuan untuk menguji hipotesis yang telah ditetapkan. Dengan populasi sebanyak 15000 dan sampel 100 responden dengan menggunaka rumus slovin. 


\section{Hasil dan Pembahasan}

Model persamaan regresi yang dapat dituliskan dari hasil tersebut dalam bentuk persamaan regresi sebagai berikut:

$$
\begin{array}{r}
\boldsymbol{Y}=\boldsymbol{a}+\boldsymbol{b}_{1} \boldsymbol{x}_{\mathbf{1}}+\boldsymbol{b}_{\mathbf{2}} \boldsymbol{x}_{\mathbf{2}}+\boldsymbol{b}_{\mathbf{3}} \boldsymbol{x}_{\mathbf{3}} \\
\mathrm{Y}=0,721+0,489 \mathrm{X} 1+0,147 \mathrm{X} 2+0,124 \mathrm{X} 3+\mathrm{E}
\end{array}
$$

Adapun penjelesan dari hasil regresi diatas sebagai berikut:

1. $a=0,721$ artinya perpotongan garis regresi dengan sumbu $\mathrm{Y}$ yang menunjukan tingkat kepuasan (Y) ketika variabel independennya yaitu sumber daya manusia proses jasa dan sarana fisik bernilai 0 atau konstan.

2. $b_{1}=$ artinya setiap peningkatan sumber daya manusia (X1) sebesar 1 premi maka akan berubah kepuasan masyarakat (Y) sebesar 0,489 satuan, apabila variabel lainnya seperti proses jasa dan sarana fisik dianggap konstan.

3. $b_{2}=$ artinya setiap peningkatan proses jasa (X2) sebesar 1 premi maka akan berubah kepuasan masyarakat (Y) sebesar 0,147 satuan, apabila variabel lainnya seperti sumber daya manusia dan sarana fisik dianggap konstan.

4. $b_{3}=$ artinya setiap peningkatan sarana fisik (X3) sebesar 1 premi maka akan berubah kepuasan masyarakat (Y) sebesar 0,124 satuan, apabila variabel lainnya seperti proses jasa dan sumber daya manusia dianggap konstan.

\section{A. Uji hipotesis simultan}

Dilakukan untuk mengetahui seberapa besar pengaruh seluruh variabel independen terhadap variabel dependen. Hasil uji hipotesis secara simultan adalah sebagai berikut:

$\mathrm{H} 0: \beta 1 \beta 2=0$ : Tidak terdapat pengaruh antara variabel sumber daya manusia (X1) proses jasa (X2) dan sarana fisik (X3) terhadap kepuasan $\mathrm{H} 0: \beta 1 \beta 2 \neq 0$ : Terdapat pengaruh antara variabel sumber daya manusia (X1) proses jasa (X2) dan sarana fisik (X3) terhadap kepuasan (Y) dengan derajat kebebasan $(\mathrm{df})=\mathrm{n}-\mathrm{k}=96 \mathrm{k}-1=3$

bahwa nilai $\mathrm{F}$ hitung sebesar 83,842 dimana kriteria penolakan Ho jika $\mathrm{F}$ hitung lebih besar dari $\mathrm{F}$ tabel maka diperoleh nilai $\mathrm{F}$ tabel adalah 2,70 atau 83,842 > 2,70 dan probabilitas F (Fsig) < 5\%, H_a: $\rho \_\left(Y X \_1\right)=\rho \_\left(Y X \_2\right) \neq 0$ maka H0 ditolak artinya variabel sumber daya manusia proses jasa dan sarana fisik secara simultan memiliki pengaruh terhadap kepuasan masyarakat.

\section{B. Uji hipotesis parsial}

Dilakukan untuk mengetahui pengaruh variabel independen secara parsial terhadap variabel independen. Berdasarkan perhitungan yang telah dilakukan untuk mengetahui pengaruh variabel independen sumber daya manusia proses jasa sarana fisik terhadap variabel independen kepuasan masyarakat didapatkan hasil sebagai berikut:

$\mathrm{H} 0: \beta 1=0$ : Tidak terdapat pengaruh antara variabel sumber daya manusia (X1) terhadap kepuasan (Y)

Ha : $\beta 1 \neq 0$ : Terdapat pengaruh antara variabel sumber daya manusia $(\mathrm{X} 1)$ 


\section{terhadap kepuasan (Y)}

Berdasarkan Tabel 4.51 menunjukkan bahwa probabilitas $\mathrm{t}$ (tsig) $<5 \%$,

$H_{a}: \rho_{Y X_{1}} \neq 0$ maka $\mathrm{H}_{0}$ ditolak artinya variabel sumber daya manusia memiliki pengaruh terhadap kepuasan. Selain itu probabilitas $\mathrm{t}\left(t_{\text {sig }}\right)<5 \%, H_{a}: \rho_{Y X_{2}} \neq 0$ maka $\mathrm{H}_{0}$ ditolak artinya variabel proses jasa memiliki pengaruh terhadap kepuasan dan probabilitas $\mathrm{t}\left(t_{\text {sig }}\right)<5 \%, H_{a}: \rho_{Y X_{2}} \neq 0$ maka $\mathrm{H}_{0}$ ditolak artinya variabel sarana fisik memiliki pengaruh terhadap kepuasan masyarakat.

\section{Tanggapan Masyarakat Tentang Sumber Daya Manusia}

Berdasarkan pertanyaan yang diajukan melalui pembagian kuesioner terhadap responden didapatkan hasil bahwa tanggapan masyarakat mengenai kemampuan aparatur desa dalam menyelesaikan pekerjaan kepada masyarakat dinilai baik dalam hal penguasaha teknologi komputer. Kepala desa tetap dituntut melakukan pengembangan pelatihan aparatur desa dalam upaya untuk meningkatkan kemampuan sehingga dapat melayani masyarakat desa batujajar barat dengan baik dan maksimal.

Selanjutnya pengetahuan aparatur desa dalam menyelesaikan pekerjaan kepada masyarakat dinilai baik ini sejalan dengan pertanyaan butir 1 dilihat dari kemampuan aparatur desa yang dinilai baik hal tersebut menjelaskan bahwa kepala desa tetap dituntut melakukan pengembangan pelatihan dalam upaya untuk meningkatkan kemampuan sehingga dapat melayani masyarakat desa batujajar barat dengan baik dan maksimal.

Selanjutnya aparatur desa selalu berprilaku sopan dalam bekerja kepada masyarakat dinilai baik aparatur desa selalu berprilaku jujur dalam bekerja kepada masyarakat dinilai baik, aparatur desa selalu berprilaku ramah ketika bekerja melayani masyarakat dinilai baik aparatur desa selalu berprilaku disiplin ketika bekerja melayani masyarakat dinilai baik aparatur desa selalu berpakaian rapih ketika bekerja melayani masyarakat dinilai kurang rapih aparatur desa selalu bertanggung jawab terhadap pekerjaannya melayani masyarakat dinilai baik.

Dilihat dari ke 5 butir pertanyaan diatas menunjukan sikap dan prilaku aparatur desa belum menunjukan sikap dan prilaku yang baik untuk mengatasi hal tersebut perlu dikembangkan budaya organisasi yang baik yang selalu mengedepankan senyum sapa salam kepada masyarakat.

Dilihat dari tanggapan masyarakat tentang sumber daya manusia aparatur desa secara akumulatif bahwa masyarakat menilai aparatur desa batujajar barat memiliki kemampuan dan sikap yang baik dan sejatinya harus ditunjukan kepada masyarakat peran aparatur desa sangatlah penting karena aparatur desa berperan langsung kedalam proses penyampaian jasa kepada masyarakat baik atau tidaknya suatu pemerintahan desa dilihat dari kualitas sumber daya manusia aparatur desa oleh karena itu kepala desa harus melakukan kegiatan pengembangan pelatihan terhadap aparatur desa yang bertujuan untuk meningkatkan kemampuan pengetahuan sikap dan prilaku agar penyampaian jasa berjalan dengan baik.

\section{Tanggapan Masyarakat Tentang Proses Jasa Desa Batujajar Barat}


Berdasarkan pertanyaan yang diajukan melalui pembagian kuesioner terhadap responden didapatkan hasil bahwa tanggapan masyarakat mengenai kecepatan aparatur desa dalam menyelesaikan layanan kepada masyarakat dinilai baik.

Selanjutnya kecepatan aparatur desa dalam menyelesaikan keluhan masyarakat dinilai baik. Dari kedua butir pertanyaan diatas menjelaskan bahwa kemampuan aparatur desa yang salah satu indikator nya adalah kecepatan dalam menyelesaikan pekerjaan dinilai masyarakat baik. Hal ini sejalan dengan kemampuan dan pengetahuan aparatur desa yang baik maka solusi yang harus tetap dilakukan adalah dengan melakukan pengembangan pelatihan dalam upaya untuk meningkatkan kemampuan pengetahuan sehingga dapat melayani masyarakat desa batujajar barat dengan baik.

Selanjutnya aparatur desa memberikan kepastian waktu pelayanan kepada masyarakat aparatur desa memberikan kepastian biaya pelayanan kepada masyarakat aparatur desa memberikan kepastian waktu penyelesaian pelayanan kepada masyarakat aparatur desa kurang terbuka terhadap biaya administrasi yang harus dibebankan oleh masyarakat aparatur desa kurang terbuka terhadap prosedur pelayanan kepada masyarakat dilihat dari kelima butir pertanyaan diatas dapat dijelaskan bahwa sikap dan prilaku aparatur desa terbuka kepada masyarakat keterbukaan, dalam arti bahwa prosedur/ tata cara persyaraan, satuan kerja/ pejabat dan hal-hal lain, yang berkaitan dengan proses pelayanan umum wajib diinformasikan secara terbuka agar mudah diketahui dan dipahami masyrakat, baik diminta maupun tidak diminta, Efisien meliputi persyaratan pelayanan umum hanya dibatasi pada hal-hal berkaitan langsung dengan pencapaian sasaran pelayanan dengan tetap memperhatikan keterpaduan antara persyaratan dengan produk pelayanan umum yang diberikan.

Selanjutnya kemudahan dalam memperoleh pelayanan kepada masyarakat dinilai baik, Kemudahan alur prosedur pelayanan kepada masyarakat dinilai kurang baik dari kedua butir pertanyaan tersebut aparatur desa sebaiknya melakukan sosialiasi terhadap prosedur atau tahap tahap yang harus ditempuh masyarakat dalam membuat layanan administrasi seperti pembuatan surat ijin usaha, surat akta tanah dan yang lainnya yang bertujuan untuk memnberikan informasi kepada masyarakat sehingga kemudahan alur prosedur akan tercipta. Sosialiasi tersebut dapat dilakukan dengan membuat poster diagram plow, banner atau spanduk mengenai alur prosedur kemudian di tempel di gedung desa batujajar barat.

Dilihat dari tanggapan masyarakat tentang proses jasa secara akumulatif bahwa masyarakat menilai proses jasa di desa batujajar barat baik hal ini dapat disebabkan oleh baiknya kemampuan dan pengetahuan aparatur desa. Solusi yang dapat dilakukan adalah tetap melakukan pengembangan pelatihan aparatur desa dengan meningkatnya kemampuan dan pengetahuan secara langsung akan meningkatkan proses jasa lebih efektif dan efisien. Sesuai Pasal 24 UU Nomor 62014 guna meningkatkan pelayanan kepada masyarakat secara optimal maka pemerintahan desa harus menyelenggarakan pelayanan berdasarkan asas: kepastian hukum, tertib, 
penyelenggaraan pemerintahan, tertib kepentingan umum, keterbukaan. proporsionalitas profesionalitas, akuntabilitas efektivitas dan efisiensi dan pada akhirnya untuk meningkatkan kepuasan masyarakat.

\section{E. Tanggapan Masyarakat Tentang Sarana Fisik Desa Batujajar Barat}

Berdasarkan pertanyaan yang diajukan melalui pembagian kuesioner terhadap responden didapatkan hasil bahwa tanggapan masyarakat baik mengenai gedung serba guna pemerintahan desa dinilai sangat baik gedung desa batujajar barat dinilai sangat bersih kondisi gedung pemerintahan desa batujajar barat dinilai sangat baik pencahayaan gedung pemerintahan desa dinilai sangat baik.

Selanjuntnya sarana parkir gedung pemerintahan desa batujajar barat dinilai kurang baik ketersediaan ruang tunggu desa batujajar barat dinilai kurang baik ruang pelayanan pemerintahan desa dinilai kurang nyaman dari ke 6 butir pertanyaan diatas dapat disimpulan bahwa sarana pendukung pelayanan jasa kepada masyarakat masih kurang baik maka dari itu pemerintahan desa perlu melakukan perbaikan perbaikan seperti kenyamanan ruang tunggu ketersediaan ruang tunggu yang bertujuan untuk meningkatkan kenyamanan pengguna layanan jasa.

Selanjutnya masyarakat menilai kualitas jalan desa dan kualitas irigasi di desa batujajar barat dinilai kurang baik dalam upaya untuk meningkatkan taraf hidup masyarakat dan memperlancar roda perekonomian di desa maka pemerintahan desa harus memperbaiki sarana jalan desa sesuai sebagaimana yang dikatakan dalam peraturan gubernur jawa barat no 45 tahun 2015 nomer 5 pembangunan desa adalah upaya untuk meningkatkan kualitas hidup dan kehidupan dalam memperoleh layanan guna meningkatkan kualitas hidup.

\section{F. Tingkat Kepuasan Masyarakat Desa Batujajar Barat}

Berdasarkan hasil penelitian yang telah dilakukan jumlah akumulasi rata-rata kepuasan masyarakat dalam kategori kurang puas. Tanggapan masyarakat tentang kepuasan berdasarkan hasil survei yang telah dilakukan terhadap ke 7 butir pertanyaan.

Berdasarkan pertanyaan yang diajukan melalui pembagian kuesioner terhadap responden didapatkan hasil bahwa tanggapan masyarakat puas terhadap pelayanan aparatur desa batujajar barat masyarakat puas terhadap kepemimpinan kepala desa batujajar barat masyarakat puas terhadap kemudahan prosedur pelayanan masyarakat tidak puas terhadap kemudahan memperoleh pelayanan masyarakat puas terhadap sarana parkir desa yang luas masyarakat puas terhadap tempat pelayanan masyarakat puas terhadap gedung desa batujajar barat.

Kepuasan merupakan perasaan senang atau kecewa setelah membandingkan kinerja aktual dengan harapan. Apabila kinerja melebihi harapan maka masyarakat akan merasa puas, sebaliknya apabila kinerja di bawah harapan maka masyarakat akan merasa kecewa. Untuk itu pemerintahan desa batujajar barat harus meningkatkan kinerja sumber daya manusia yang paling utama karena dengan baik 
nya kualitas sumber daya manusia akan berdampak pada baiknya proses jasa dan sarana fisik di desa batujajar barat yang bertujuan untuk mencapai tingkat kepuasan masyarakat.

\section{G. Pengaruh Sumber Daya Manusia Proses Jasa dan Sarana Fisik Terhadap Kepuasan Masyarakat Desa Batujajar Barat}

Pada penelitian ini peneliti mencoba meneliti pengaruh variabel sumber daya manusia proses jasa dan sarana fisik terhadap kepuasan secara simultan berdasarkan hasil uji hipotesis didapatkan hasil sumber daya manusia proses jasa dan sarana fisik secara simultan memiliki nilai yang signifikan terhadap variabel kepuasan dilihat dari hasil uji $\mathrm{F}$ dimana $\mathrm{F}$ sig $<5 \%$ yang berarti $\mathrm{H} 0$ ditolak $\mathrm{H} 1$ diterima. Hal ini menunjukkan bahwa sumber daya manusia proses jasa dan sarana baik merupakan variabel yang penting atau berarti secara simultan mempengaruhi kepuasan masyarakat. Hasil penelitian ini pun di dukung dari teori yang menurut (Lupiyoadi \& Hamdani, 2011) faktor-faktor yang mempengaruhi kepuasan konsumen adalah bauran pemasaran yang terdiri dari: people (orang) yaitu mengenai kualitas orang yang terlibat dalam pemberian pelayanan, berhubungan dengan seleksi, training, motivasi dan manajemen sdm. Untuk mencapai kualitas terbaik, pegawai harus dilatih untuk menyadari bahwa hal terpenting adalah memberi kepuasan kepada konsumen. Process (proses) yaitu bagaimana proses dalam operasi pelayanan tersebut, adalah gabungan semua aktifitas yang umumnya terdiri dari prosedur, jadwal pekerjaan, mekanisme, aktivitas dan hal-hal rutin, dimana pelayanan dihasilkan dan disampaikan kepada masyarakat.

Hal yang mempengaruhi kepuasan masyarakat terhadap pemerintahan desa batujajar barat berdasarkan hasil uji $\mathrm{F}$ serempak adalah sumber daya manusia proses jasa dan sarana fisik dimana jika sumber daya manusia aparatur desa baik memiliki kemampuan, pengetahuan sikap dan prilaku yang baik berdasarkan hasil uji F secara langsung akan meningkat kan kepuasan masyarakat.

Selanjutnya proses jasa semua aktifitas yang umumnya terdiri dari prosedur, jadwal pekerjaan, mekanisme, aktivitas dan hal-hal rutin, dimana pelayanan dihasilkan dan disampaikan kepada masyarakat jika proses jasa tersebut cepat mudah terbuka tepat waktu dan memberikan kepastian terhadap penyelesaian layanan masyarakat berdasarkan hasil uji $\mathrm{F}$ akan meningkatkan kepuasan masyarakat.

Sarana fisik merupakan gambaran langsung yang dapat dilihat oleh masyarakat untuk meningkatkan kepuasan, dimana jika sarana fisik desa batujajar barat baik dan memadai seperti baiknya gedung pemerintahan desa baiknya sarana tenpat duduk baiknya kualitas jalan desa berdasarkan hasil uji $\mathrm{F}$ akan meningkatkan kepuasan masyarakat.

Selanjutnya peneliti melakukan ujikorelasi diperoleh hasil yang paling kuat hubungan terhadap kepuasan adalah variabel sumber daya manusia, sehingga dapat diartikan bahwa sumber daya manusia variabel yang berperan penting terhadap kepuasan masyarakat dimana sumber daya manusia yang memiliki pengetahuan 
kemampuan prilaku sikap yang baik akan mengahasilkan kualitas jasa yang baik dan dapat meningkatkan kepuasan.

Dari penjelasan dan hasil uji $\mathrm{F}$ dapat disimpulkan bahwa hipotesis sumber daya manusia proses jasa dan sarana fisik berpengaruh secara siginifikan terhadap kepuasan masyarakat secara simultan dan dapat diterima.

\section{Kesimpulan}

Kesimpulan menyeluruh untuk penelitian ini, yaitu sebagai berikut: 1) Tanggapan masyarakat mengenai sumber daya manusia aparatur desa batujajar barat berada pada posisi baik dalam hal kemampuan pengetahuan kompetensi sikap profesionalitas penampilan sehingga perlu ditingkatkan mengenai kemampuan pengetahuan sikap aparatur desa; 2) Tanggapan masyarakat mengenai proses jasa di pemerintahan desa batujajar barat berada pada posisi baik dalam hal kecepatan keterbukaan kepastian efektifitas efesiensi kemudahan sehingga perlu ditingkatkan mengenai kecepatan kemudahan kepastian dan memberikan kepastian waktu penyelesaian; 3) Tanggapan masyarakat mengenai sarana fisik desa batujajar barat berada pada posisi baik sehingga perlu dilakukan pembenahan seperti kualitas gedung pelayanan, sarana ruang, tunggu pelayanan, kualitas jalan desa; 4) Tanggapan masyarakat mengenai kepuasan terhadap pemerintahan desa batujajar barat secara kesuluruhan berada dalam posisi tidak puas dimana indikator yang mempengaruhi terdiri dari variabel sumber daya manusia, proses jasa dan sarana fisik yang ada di pemerintahan desa batujajar barat; 5) Besarnya pengaruh sumber daya manusia proses jasa dan sarana fisik mempunyai pengaruh yang signifikan secara simultan dan parsial dimana hubungan terbesar adalah variabel sumber daya manusia. 


\section{BIBLIOGRAFI}

Amstrong. (2012). Prinsip-prinsip Pemasaran. Jilid 1. Jakarta: Erlangga.

Barata, Atep Adya. (2004). Dasar-Dasar Pelayanan Prima. Cetakan Kedua. Jakarta: PT. Elex Media Komputindo.

Dwi, Agustina B. (2009). Eksperimentasi Pembelajaran Matematika Melalui Strategi Think Talk Write (TTW) Dan Pendekatan Realistic Mathematic Educations (RME) Terhadap Kemampuan Menyelesaikan Soal-Soal Matematika Pada Siswa. Universitas Muhammadiyah Surakarta. Skripsi.

Fandy, Tjiptono. (2011). Service Management Mewujudkan Layanan Prima. Edisi 2. Yogyakarta: Andi.

Ilyas, Muhammad, Sudaryanto, Agus, Setiawan, Iwan Eka, Riyadi, Adi Slamet, Isobe, Tomohiko, Takahashi, Shin, \& Tanabe, Shinsuke. (2010). Characterization Of Polychlorinated Biphenyls And Brominated Flame Retardants In Sediments From Riverine And Coastal Waters Of Surabaya, Indonesia. Marine Pollution Bulletin, 62(1), 89-98.

Khoirul, Akbar Irfan. (2012). Pengaruh Kualitas Pelayanan Terhadap Kepuasan Nasabah Pada Pt Bank X Cabang Bandung Surapati. Universitas Sanata Dharma. Skripsi.

Kotler, Philip, \& Keller, Kevin Lane. (2012). Manajemen Pemasaran. Edisi Ketiga Belas Jilid 1 dan 2. Dialih Bahasakan Oleh Bob Sabran. Jakarta: Erlangga.

Lupiyoadi, Rambat, \& Hamdani, A. (2011). Manajemen Pemasaran Jasa” Edisi 2. Jakarta: Salemba Empat.

Mulyawan, Ali, \& Rinawati, Rinawati. (2017). Pengaruh Kualitas Layanan Akademik Terhadap Kepuasan Mahasiswa Serta Implikasinya Pada Loyalitas Mahasiswa (Studi Pada Sekolah Tinggi Manajemen Informatika Dan Komputer Di Kota Bandung). Jurnal Ekonomi, Bisnis \& Entrepreneurship, 10(2), 119-131.

Nasution, Fitra Arlina. (2011). Analisis Pengaruh Bauran Pemasaran Jasa Terhadap Kepuasan Dan Loyalitas Nasabah Tabungan Simpedes Pada PT Bank Rakyat Indonesia (Persero) Tbk Unit Deli Tua Medan. Universitas Sumatera Utara. Skripsi.

Qomariah, Nurul. (2012). Pengaruh Kualitas Layanan Dan Citra Institusi Terhadap Kepuasan Dan Loyalitas Pelanggan (Studi Pada Universitas Muhammadiyah Di Jawa Timur). Jurnal Aplikasi Manajemen, 10(1), 177-187.

Setiawan, T., Brahmantyo, B., \& Irawan, D. E. (2008). Analisis Kelurusan Morfologi 
Kajian Sumber Daya Manusia Proses Jasa Sarana Fisik dan Dampaknya pada Kepuasan Masyarakat

Untuk Interpretasi Hidrogeologi Kars Cijulang, Kabupaten Ciamis, Provinsi Jawa Barat. Prosiding PIT IAGI Ke, 37.

Sudiarta. (2011). Strategi Pemasaran: Mengintegrasikan Konsep Pemasaran Pariwisata, Gaya Hidup Konsumen dan Manajemen Destinasi Pariwisata Menuju Kualitas Pengalaman Berkelanjutan. Jurnal Manajemen dan Akuntansi, 16(2).

Sufiyyah, Arrafiatus. (2011). Pengaruh Kualitas Layanan Akademik dan Birokrasi terhadap Kepuasan Mahasiswa. Jurnal Ilmiah Aset, 13(2), 85-93.

Sugiyono, Prof Dr. (2013). Metode Penelitian Manajemen. Bandung: Alfabeta, CV.

Suprapti, Ni Wayan Sri. (2010). Perilaku Konsumen: Pemahaman Dasar Dan Aplikasinya Dalam Strategi Pemasaran. Denpasar: Udayana University Press

Suyanto, Bagong.(2013). Sosiologi Ekonomi. Jakarta: Kencana. 